Article

\title{
Influences on Adaptive Planning to Reduce Flood Risks among Parishes in South Louisiana
}

\author{
Mary Paille *, Margaret Reams, Jennifer Argote, Nina S.-N. Lam and Ryan Kirby \\ Department of Environmental Sciences, School of the Coast and the Environment, Louisiana State University, \\ 1271 Energy Coast and Environment Building, Louisiana State University, Baton Rouge, LA 70803, USA; \\ mreams@lsu.edu (M.R.); jennifer.argote@gmail.com (J.A.); nlam@lsu.edu (N.S.N.L.); rkirby3@lsu.edu (R.K.) \\ * Correspondence: mpaill1@lsu.edu; Tel.: +1-225-578-7173
}

Academic Editor: Ataur Rahman

Received: 16 November 2015; Accepted: 27 January 2016; Published: 6 February 2016

\begin{abstract}
Residents of south Louisiana face a range of increasing, climate-related flood exposure risks that could be reduced through local floodplain management and hazard mitigation planning. A major incentive for community planning to reduce exposure to flood risks is offered by the Community Rating System (CRS) of the National Flood Insurance Program (NFIP). The NFIP encourages local collective action by offering reduced flood insurance premiums for individual policy holders of communities where suggested risk-reducing measures have been implemented. This preliminary analysis examines the extent to which parishes (counties) in southern Louisiana have implemented the suggested policy actions and identifies key factors that account for variation in the implementation of the measures. More measures implemented results in higher CRS scores. Potential influences on scores include socioeconomic attributes of residents, government capacity, average elevation and past flood events. The results of multiple regression analysis indicate that higher CRS scores are associated most closely with higher median housing values. Furthermore, higher scores are found in parishes with more local municipalities that participate in the CRS program. The number of floods in the last five years and the revenue base of the parish does not appear to influence CRS scores. The results shed light on the conditions under which local adaptive planning to mitigate increasing flood risks is more likely to be implemented and offer insights for program administrators, researchers and community stakeholders.
\end{abstract}

Keywords: planning; resilience; adaptive governance; community rating system; NFIP

\section{Introduction}

Since Hurricanes Katrina and Rita of 2005, risk awareness has grown among stakeholders of coastal Louisiana communities facing increasing flood risks from sea-level rise, intense storms and land subsidence. Like many other coastal regions, population growth along the Louisiana coast combined with limited land use planning has exacerbated these risks. For example, by the end of the 21st century, annual flood costs in the United States could increase from $\$ 2$ billion to $\$ 7-\$ 19$ billion because of climate change, urbanization and urban emissions [1]. The National Flood Insurance Program (NFIP), designed to provide affordable insurance to property owners in flood-prone areas, is running a $\$ 25$ billion deficit in the wake of recent catastrophic storms [2]. Efforts by the U.S. Congress in 2012 to increase policyholders' premiums to more accurately cover the costs of property insurance in high risk regions were met with intense opposition from coastal stakeholders [3,4]. Given the inherent political and scientific challenges involved in setting and collecting higher premium rates for NFIP policyholders, the role to be played by local communities in formulating and implementing proactive planning to reduce overall exposure risks becomes even more important. 
The Community Rating System (CRS) of the NFIP provides incentives to local communities to enact collective measures to mitigate flood risks. This analysis builds on the earlier work of several studies that examined contextual factors that may explain variation in CRS participation and helped shed light on the conditions under which local collective action may be more likely. This is especially relevant for researchers and stakeholders of Louisiana, where no previous study has examined CRS participation and given the historical ambivalence among counties and local communities concerning planning and land use management efforts [5]. Although proactive planning could help Louisiana communities increase resiliency to large-scale disturbances, enacting such land use plans requires technical information, economic resources and political will. As a result, collective actions may be more difficult to formulate and implement in some communities.

The objectives of this study are to examine the CRS participation rates and performance of parishes (counties) in south Louisiana and to identify key factors associated with greater implementation of the CRS flood risk-reducing measures.

\subsection{The Community Rating System}

The CRS is a voluntary incentive program designed to encourage communities to implement structural and non-structural flood risk-reduction measures beyond minimum NFIP requirements. Participating communities are evaluated and given a score based on the number of planning milestones they have met. The CRS scores reflect a range of activities, including implementation of land-use controls, such as preservation of floodplain as open space, regulation of development in flood-risk areas and watersheds and development of a comprehensive floodplain management plan. These measures result in a discounted flood insurance rate for National Flood Insurance Program (NFIP) policyholders in that community. NFIP discounts flood insurance rates based on a point system that ranges from $5 \%$ to $45 \%$, increasing in $5 \%$ increments, corresponding to the score, or total number of points received $[6,7]$.

CRS communities vary in size and may include local municipalities and parishes. Each jurisdiction within a parish has the opportunity to participate in the CRS program and is not considered part of a county-wide CRS program. In other words, if decision makers of an incorporated municipality want CRS program discounts, they must enact their own separate CRS program, distinct from the county program. Thus, the county-level CRS programs cover residents and communities within the unincorporated areas of the county.

The CRS program seeks to further three broad goals: to reduce and avoid flood damage to insurable property; to strengthen and support insurance aspects of the NFIP; and to foster comprehensive floodplain management. Following reorganization in 2013, the program focuses on six core flood-loss reduction areas: reduction of liabilities to the NFIP fund; improvement of disaster resiliency and sustainability of communities; integration of a "Whole Community" approach to address emergency management; promotion of natural and beneficial functions of floodplains; increased understanding of risk; and adoption and enforcement of disaster-resistant building codes [6]. The CRS encourages 19 activities or measures, organized into four categories: public information, mapping and regulations, flood damage reduction (structural and non-structural) and flood preparedness. Communities can also request that FEMA review other flood risk-reduction measures not listed in the program for additional CRS points.

Table 1 summarizes the types of planning and policy activities that are encouraged through the CRS program. The table shows the various activities under which communities can earn points through the CRS program, grouped into four categories (Series 300, 400, 500, 600). Each activity has a maximum number of points obtainable; however, most communities do not obtain the maximum amount of points. An average for all CRS communities in the program and an average for Louisiana communities are also included as a reference. 
Table 1. The Community Rating System (CRS) activities and credit point system [6,7].

\begin{tabular}{ccccc}
\hline Series $\mathbf{3 0 0}$ & Public Information & Maximum Points & National Average & Louisiana Average \\
\hline 310 & Elevation Certificates & 162 & 68 & 66 \\
320 & Map Information Service & 140 & 140 & 140 \\
330 & Outreach Projects & 380 & 99 & 80 \\
340 & Hazard Disclosure & 81 & 14 & 15 \\
350 & Flood Protection Information & 102 & 45 & 46 \\
360 & Flood Protection Assistance & 71 & 47 & 51 \\
370 & Flood Insurance Promotion * & 0 & 0 & 0 \\
& Total & 936 & 413 & 398 \\
\hline Series $\mathbf{4 0 0}$ & Mapping and regulations & Maximum Points & National Average & Louisiana Average \\
\hline 410 & Additional Flood Data & 1346 & 89 & 56 \\
420 & Open Space Preservation & 900 & 182 & 93 \\
430 & Higher Regulatory Standards & 2740 & 291 & 167 \\
440 & Flood Data Maintenance & 239 & 97 & 82 \\
450 & Stormwater Management & 670 & 111 & 71 \\
& Total & 5895 & 770 & 469 \\
\hline Series 500 & Flood Damage Reduction & Maximum Points & National Average & Louisiana Average \\
\hline 510 & Floodplain Management Planning & 359 & 129 & 135 \\
520 & Acquisition and Relocation & 3200 & 237 & 121 \\
530 & Flood Protection & 2800 & 79 & 68 \\
540 & Drainage System Maintenance & 330 & 201 & 224 \\
& Total & 6689 & 646 & 548 \\
\hline Series $\mathbf{6 0 0}$ & Flood Preparedness & Maximum Points & National Average & Louisiana Average \\
\hline 610 & Flood Warning Program & 255 & 93 & 110 \\
620 & Levee Safety & 900 & 93 & 69 \\
630 & Dam Safety & 175 & 63 & 179 \\
\hline
\end{tabular}

Note: * Flood Insurance Promotion, Activity 370, was a new activity in 2013, and therefore, no community has earned these points as of publication. Below is a summary of each activity, taken directly from the 2014 CRS Manual.

\subsubsection{Public Information Activities (300 Series)}

Measures under this category include those that advise people about the flood hazard, encourage the purchase of flood insurance and provide information about ways to reduce flood damage. These activities also generate data needed by insurance agents for accurate flood insurance rating. They generally serve all members of the community.

\subsubsection{Mapping and Regulations (400 Series)}

This series credits programs that provide increased protection to new development. These activities include mapping areas not shown on the Flood Insurance Rate Maps (FIRMs), preserving open space, protecting natural floodplain functions, enforcing higher regulatory standards and managing stormwater. The credit is increased for growing communities.

\subsubsection{Flood Damage Reduction Activities (500 Series)}

These measures attempt to protect existing development, which is considered to be at risk within the participating jurisdiction. Credit is provided for a comprehensive floodplain management plan, relocating or retrofitting flood-prone structures and maintaining drainage systems.

\subsubsection{Warning and Response (600 Series)}

This series provides credit for measures that protect life and property during a flood, through flood warning and response programs. There is credit for the maintenance of levees and dams and also for programs that prepare for their potential failure. 
Community class rankings in the CRS range from 1 to 10 . A Class 1 community can receive the highest insurance rate discount of $45 \%$. A Class 9 community can receive a $5 \%$ discount. A Class 10 community either has failed to receive a minimum number of points or has become inactive in the program and does not receive a discount. In order for a community to become a member of the CRS program, it must be in good standing with NFIP regulations (has adopted and enforced NFIP floodplain management regulations that conform to NFIP standards) and appoint a CRS coordinator to handle all application work. Further, the CRS requires that communities actually implement these plans and monitor activities annually as a condition for renewal. Each year, communities must re-certify under the CRS program to ensure that the community is still performing the tasks for which it has received CRS points. Furthermore, a new CRS class will not be enacted until the next point tier is reached. Therefore, a community with 1000 points will have the same CRS class of 8 as a community with 1498 points. CRS class changes occur in May and October of each year. If the community does not renew each year, its residents will lose any NFIP rate discounts [8,9]. It is noteworthy that residents living in the more flood-prone Special Flood Hazard Area (SFHA) are required to have flood insurance, and most purchase policies through the NFIP.

Table 2 displays the NFIP insurance premium reductions associated with the total CRS points and the number of Louisiana parishes in each of the rate-reduction categories.

Table 2. The CRS points and classification system [6]. SFHA, Special Flood Hazard Area.

\begin{tabular}{ccccc}
\hline $\begin{array}{c}\text { Credit Points } \\
\text { (Score) }\end{array}$ & Class & \multicolumn{2}{c}{ Premium Reduction } & \begin{tabular}{c} 
Number of Louisiana \\
\cline { 3 - 4 } Parishes
\end{tabular} \\
\hline $4500+$ & 1 & $45 \%$ & $10 \%$ & 0 \\
$4000-4499$ & 2 & $40 \%$ & $10 \%$ & 0 \\
$3500-3999$ & 3 & $35 \%$ & $10 \%$ & 0 \\
$3000-3499$ & 4 & $30 \%$ & $10 \%$ & 0 \\
$2500-2999$ & 5 & $25 \%$ & $10 \%$ & 0 \\
$2000-2499$ & 6 & $20 \%$ & $10 \%$ & 3 \\
$1500-1999$ & 7 & $15 \%$ & $5 \%$ & 2 \\
$1000-1499$ & 8 & $10 \%$ & $5 \%$ & 8 \\
$500-999$ & 9 & $5 \%$ & $5 \%$ & 2 \\
$0-499$ & 10 & $0 \%$ & $0 \%$ & 1 \\
\hline
\end{tabular}

As of October 2015, the CRS program had 1368 participating communities in the United States, or approximately $5 \%$ of the total NFIP communities present. Roseville, California, is the only Class 1 ranked community in the United States [10]. Louisiana currently has 46 communities participating in the program. Of those 46,16 are parishes and 30 are municipalities of varying size and population [11].

\subsection{CRS Activities and Community Resilience}

Historically, Louisiana communities have been slow to adopt planning measures [12], despite the potential benefits in terms of reducing exposure to flood risks. As a largely rural state, many parishes lack the resources to implement and maintain parish-wide measures, such as open-space preservation or floodplain management. Furthermore, since stakeholders of many smaller and more rural communities do not feel the pressure to implement growth management strategies, they may not recognize the benefits or relevance of planning in terms of disaster prevention and/or flood reduction [13,14]. However, smarter growth strategies and other land use planning measures may lessen the vulnerability (and increase the resiliency) of a community $[15,16]$. Common examples of smarter growth strategies include growth restrictions in flood-prone areas and tighter building codes and regulations [17]. However, as pressure for more development and housing grows, pressure to develop in floodplains increases, and therefore, more individual properties are exposed to risk [18-20].

In 2007, the United States Federal Emergency Management Agency (FEMA) ranked Florida, California, Texas, Louisiana and New Jersey respectively as highest risk for flooding based on a composite risk score derived from floodplain area, per capita housing and number of housing. 
Researchers found that "non-structural" methods, such as those measured by the CRS rating, were more than twice as effective as "structural" measures, such as dams, at reducing the level of damage from flooding $[11,18]$. Furthermore, while structural measures directly reduce flooding risk to property and communities, they can encourage development in flood-prone areas that are now protected by these measures [2]. Therefore, the types of measures encouraged by the CRS program, such as open space preservation, stormwater management and flood information disclosure, address an obvious need.

In England, the Netherlands and Germany, strong flood mapping tools drive planning decisions, as flood management efforts focus increasingly on non-structural methods. However, these tools still run the risk of remaining just that: tools. These programs still see resistance between central and local governments, individuals and professional planners [21-23]. Furthermore, even with increasing flooding events, research suggests individuals and organizations tend to minimize flooding events as recent as 10 years prior and see those events as isolated incidents, which are unlikely to occur again [18].

The CRS program with its incentives to individual NFIP policyholders, prescription of collective risk-reducing measures and annual evaluation of participating jurisdictions is an important resource for local decision makers seeking to reduce flood exposure risks. Previous research has shown that the CRS program does in fact promote discount-seeking activities [24,25]. The CRS program also introduces more interactions between local policy makers and citizens through the creation of specific risk assessments, information sharing and other educational outreach activities. Related research also shows that mitigation measures can be affected at the individual level through public information activities and hazard information disclosure, a large part of the CRS-creditable activities [26]. As such, the program may enhance public understanding of flood risks. According to Jennifer Gerbasi, the CRS coordinator for Terrebonne parish who was interviewed for this study, the CRS program promotes greater levels of trust in local officials for residents and encourages community-based decision making to reduce flood exposure risks [27].

Participation in the CRS program may encourage and support several key attributes of more resilient communities, as identified by resilience theorists. For example, Adger [28] and colleagues identified as a key attribute of resilience the ability to withstand repeated disturbances, like large-scale storms and floods, while still maintaining "essential structures, processes and feedbacks" within the system. The constituent members of resilient communities are able to "self-organize" to carry out essential functions in the aftermath of disturbances and are able to learn from their experiences and to adapt to reduce future exposure risks [28-32]. Researchers have observed that the process of recovering from major disturbances presents opportunities for expanded learning environments with greater stakeholder input into collective decisions and consideration of data from multiple sources to gain a more holistic understanding of the risks [33-35]. As a result, the public may become more involved, aware and informed of potential risks, and the political will to take collective action may increase.

Despite the opportunity to learn and adapt following large disturbances, lack of available information on flooding, inundation, land use and growth patterns can present challenges for community stakeholders to participate in informed decision making and for decision makers to formulate and implement proactive disaster management planning [36]. Furthermore, some communities in Louisiana have historically avoided land use planning, as a result of strong private property rights. Prior to Hurricane Katrina in 2005, Louisiana was among the states least likely to limit private property rights regarding planning and development and had not updated state-wide planning mandates put into place in 1927 [5,11]. While Hurricane Katrina spurred planning initiatives with the Louisiana Speaks program, Louisiana still lacks large-scale or state-wide planning efforts, with the Coastal Master Plan as the largest current planning effort.

Thus, the CRS program has an important role to play in Louisiana as community stakeholders work to reduce flood exposure risks. What factors may explain variation in parish-level measures for floodplain management and hazard mitigation evaluated under the CRS program? We turn to recent 
related research that considers the preconditions and attributes of more resilient communities, and the specific influences on CRS participation in particular, to select variables to include in our analysis.

\subsection{Factors Associated with Disaster Resilience}

In recent years, researchers have attempted to identify the most suitable indicators to assess disaster resilience. For example, in 2010, Cutter and colleagues [30] introduced the Baseline Resilience Indicator for Communities (BRIC), which is an aggregation of five sub-indexes measuring socioeconomic, institutional, infrastructural and other community capacities and attributes. Furthermore, in 2010, Sherrieb and others [8] reduced 88 variables to a smaller group of 17 variables representing two components, including social capital and economic development, as indicators of resilience. In 2015, we applied the Resilience Inference Measurement (RIM) model to measure resilience in the 52 counties of the U.S. Gulf Coast region and identified key predictors for the ability of a county to withstand exposure and damages from storms and still maintain or increase in population over time [37]. Specific factors associated with greater resilience were found to be higher elevation and greater socioeconomic resources.

Several studies have examined influences on community and household-level disaster planning. First, experience with recent floods has been found to be associated with greater community interest in and acceptance of collective planning efforts [38]. Regarding household-level measures to mitigate damages associated with floods, a survey of Tennessee residents found that individuals living in communities that experienced floods within the last year were more likely to purchase flood insurance policies [39]. The heightened awareness of flood impacts appears to have influenced residents to take action to protect their property from future floods. It is noteworthy that since 1973, the NFIP has required all properties located within the Special Flood Hazard Area to have flood insurance. However, in the Tennessee study, four years after the flood event, the number of household policies purchased through the NFIP declined, indicating a possible short-term bias in residents' risk perceptions. Similarly, Browne and Hoyt [40] found that insurance purchases are highly correlated to the level of flood losses experienced during the previous year. Others showed that proximity to flood hazards increased the likelihood that residents will purchase flood insurance [41].

Other potential influences on parish-level adaptive planning in general are the capacities and resources of the parish government. Since planning occurs at the sub-federal and sub-state level [42,43], the resources available to local policy makers may help shape planning activities and outcomes. County and local governments play an important role both in educating residents about flood risks and developing proactive disaster planning to mitigate future damages [44]. Larger county governments with more resources and staff may be better able to implement adaptive planning measures. Furthermore, stakeholders of wealthier communities have more assets to protect and inherently have a greater stake in how those assets are protected and, thus, may be likely to support more planning [10].

Finally, recent studies examining specific influences on CRS participation and implementation of risk-reducing measures point to the importance of hydrological conditions, the socioeconomic attributes of residents and government capacity. Our study builds most directly on the work of Landry and $\mathrm{Li}$ (2012) in which they examined the CRS participation of 100 counties in North Carolina from 1991 to 1996 [45]. They tested the influence of factors, including recent floods, local government capacity, socioeconomic conditions and the number of CRS participating communities within a county on CRS participation. They found that more floodplain management activities among counties with recent flood experience, greater hydrological risk and more local jurisdictions within the county also participating in the CRS program led to higher CRS scores. Sadiq and Noonan (2015) examined CRS activities throughout the nation and how they may be affected by flood risk, local government capacity and the socioeconomic attributes of residents, among other factors. They found that more hazard mitigation planning was associated with wealthier, better-educated residents [25]. Similarly, other studies have found that wealthier home owners may invest more in the protection of their property, be 
less willing to relocate and may be more supportive of local hazard mitigation efforts [44]. In a recent study of Florida counties' CRS scores, Brody and colleagues found that higher scores were associated with higher socioeconomic capital, recent flood experience and less land area located in a flood plain. Previous research also suggests that the greater amount of floodplain in a county may deter local CRS flood mitigation efforts; the costs of implementing mitigation measures may not outweigh the discount in insurance premiums [24].

These studies suggest that socioeconomic attributes of residents, county government capacity, physical factors, such as elevation, and experience with recent flood events may influence the level of CRS planning. Thus, we include indicators of these conditions and attributes of the parishes (counties) within the south Louisiana study area.

\section{Materials and Methods}

As stated previously, this analysis examines the extent to which southern Louisiana parishes have taken steps to exceed NFIP requirements to reduce local flood risks and identifies the factors that account for variation in the CRS scores among the parishes.

\subsection{Sample Selection}

The sample selected consists of the 35 parishes of South Louisiana, listed below in Table 3. Of those 35 parishes, 15 are in the CRS program. All parishes have been in the CRS program for at least 19 years, except for Lafayette Parish, which joined the program in 2011. We selected only the parishes involved in the CRS program (leaving out smaller municipalities) in order to use readily-available demographic and flood-related data. The only Louisiana parish listed in the CRS program outside of our study area was Caddo Parish in Northwest Louisiana.

Table 3. Parishes and CRS points in the study area.

\begin{tabular}{cccc}
\hline Parish & CRS Points & Parish & CRS Points \\
\hline Acadia & - & Plaquemines & - \\
Allen & - & Pointe Coupee & - \\
Ascension & 1690 & St. Bernard & - \\
Assumption & - & St. Charles Parish & 1730 \\
Beauregard & - & St Helena & - \\
Calcasieu & 1392 & St. James Parish & 1547 \\
Cameron & - & St. John the Baptist & 1006 \\
East Baton Rouge & 2068 & St. Landry & - \\
East Feliciana & - & St Martin & - \\
Evangeline & - & St. Mary & - \\
Iberia & - & St. Tammany & 1716 \\
Iberville & - & Tangipahoa & 642 \\
Jefferson & 2213 & Terrebonne & 2021 \\
Jefferson Davis & - & Vermilion & - \\
Lafayette & 1329 & Washington & - \\
Lafourche & 0 & West Baton Rouge & 1638 \\
Livingston & 845 & West Feliciana & - \\
Orleans & 1039 & & \\
\hline
\end{tabular}

\subsection{Dependent Variable}

The dependent variable is taken directly from each parish's CRS score. We used this score (as opposed to the CRS class level) in order to be able to statistically analyze a continuous variable. The scores range from a low of 0 to the highest parish score of 2213.

The independent variables included in this analysis are summarized below in Table 4. Drawing from recent related research, we chose to include measures of socioeconomic conditions, government capacity and flood exposure risk. Given the relatively small number of parishes in the study area (36), 
we limited the number of independent variables to be considered in the analysis. The average housing value is included to capture the relative affluence within the county and the value of the properties at risk of flooding. We also included the college education rate among the residents as an indicator of the socioeconomic attributes of the parish. Furthermore, the parish government revenue is included to indicate the public resources available to the county decision makers. The number of municipalities that participate in the CRS program within each parish is included to help indicate the capacity of the parish to development and implement the CRS measures. The presence of more participating jurisdictions may create a stronger base of public support for more proactive, adaptive planning to reduce flood risks. Flood risk is indicated by two variables. First, we included the number of floods over the last five years to indicate exposure to risks and the flood experiences, in addition to possible risk perceptions of the residents. The second measure of flood risk is the mean elevation of the parish, with lower elevation indicating greater flood exposure risk. The independent variables and their data sources are summarized below in Table 4.

Table 4. Independent variables.

\begin{tabular}{|c|c|c|}
\hline Variable & Variable Operation & Data Source \\
\hline \multicolumn{3}{|c|}{ Socioeconomics } \\
\hline $\begin{array}{l}\text { Median Home Value } \\
\text { College-Education Rate }\end{array}$ & $\begin{array}{l}\text { Value is an estimate of how much the } \\
\text { property (house and lot) would sell for if it } \\
\text { were for sale. Includes only specified } \\
\text { owner-occupied housing units. Dollars } \\
\text { expressed in } \$ 10,000 \text { increments. The } \\
\text { percentage of residents with college degrees }\end{array}$ & U.S. Census Bureau, 2010 \\
\hline \multicolumn{3}{|c|}{ Government Capacity } \\
\hline $\begin{array}{l}2010 \text { Government } \\
\text { Revenue }\end{array}$ & $\begin{array}{l}\text { Total expenditures for the parish } \\
\text { government for the year } 2010 \text {. }\end{array}$ & Parish Assessors' Offices, 2010 \\
\hline $\begin{array}{l}\text { Number of CRS } \\
\text { Communities }\end{array}$ & $\begin{array}{l}\text { Number of participating CRS communities } \\
\text { located in each participating CRS parish }\end{array}$ & NFIP, 2014 \\
\hline \multicolumn{3}{|c|}{ Exposure } \\
\hline Average Elevation & The number of meters above base sea level & $\begin{array}{l}\text { United States Geological Survey } \\
\text { Coastal National Elevation } \\
\text { Database Project -Topobathymetric } \\
\text { Digital Elevation Model: (USGS } \\
\text { CoNED TBDEM) } 3 \text { m, } 2014\end{array}$ \\
\hline $\begin{array}{l}\text { Number of total } \\
\text { flood events }\end{array}$ & The total number of flood events, 2006-2010 & $\begin{array}{l}\text { Spatial Hazards Events and Losses } \\
\text { Database for the United States } \\
\text { (SHELDUS), 2006-2010 }\end{array}$ \\
\hline
\end{tabular}

\subsection{Data Analysis}

We began by conducting a Pearson correlation analysis among the variables to identify any potentially highly correlated independent variables. Next, we conducted a multiple regression analysis to determine the relative statistical associations between the independent variables and the CRS scores. We conducted the analysis in SPSS Version 21. The choice of the analysis was appropriate given that the dependent variable, the CRS score, is a continuous variable. The descriptive statistics for the dependent variable and the independent variables included in the study are shown in Table 5. 
Table 5. Independent variables' descriptive statistics.

\begin{tabular}{cccccc}
\hline Independent Variable & N & Minimum & Maximum & Mean & Std. Deviation \\
\hline Total CRS Points 2013 (score) & 35 & 0 & 2213 & 596.46 & 797.02 \\
\hline \multicolumn{7}{c}{ Socioeconomics } \\
\hline Median Home Value & 35 & $79,600.00$ & $196,300.00$ & $125,914.28$ & $37,473.83$ \\
College Educated Rates & 35 & 9.7 & 34.2 & 16.63 & 6.58 \\
\hline Government Capacity & & \\
\hline 2010 Government Revenue per Person & 35 & 6.71 & 157.94 & 28.75 & 27.38 \\
CRS communities & 35 & 0.00 & 4.00 & 0.77 & 1.28 \\
\hline Average Elevation & 35 & -0.73 & 61.77 & 12.69 & 18.55 \\
2006-2010 & 35 & 0 & 21 & 2.40 & 3.86 \\
Number of total Flood Events & 35 & & & \\
\hline Valid N (listwise) & & & &
\end{tabular}

\section{Results and Discussion}

Our first research objective is to examine the level of participation in the CRS program among counties (parishes) in south Louisiana. Of the 35 parishes in the study area, 15 have achieved CRS class rankings. Figure 1 illustrates the location and CRS class of these jurisdictions. The majority of the participating parishes are located in the southeast portion of Louisiana, along with Lafayette in the central region and Calcasieu on the west side of the study area. Lafourche parish is rated a Class 10, which means it was once in the program, but is now inactive.

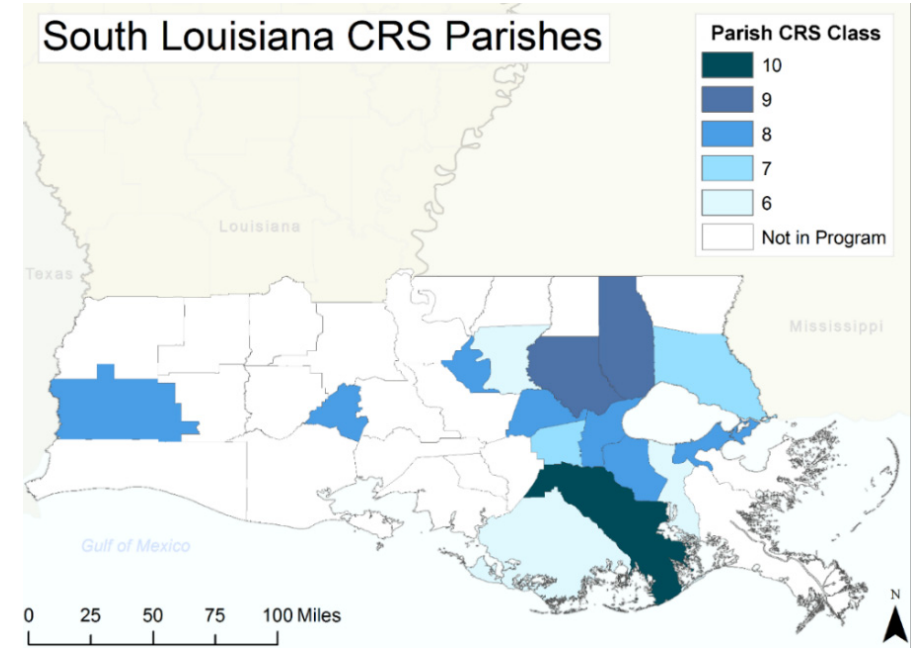

Figure 1. Map of the study area with CRS participating counties coded by CRS class ranking.

The second research objective is to identify key factors that may explain variation in the CRS scores. We conducted a Pearson bi-variate correlation analysis to identify statistically-significant associations between the variables in the analysis before constructing the multiple regression model. We considered a significant correlation value of 0.7 or higher to indicate a high degree of multicollinearity. We found that the percentage of college-educated residents was significantly and positively associated with the average housing value within the parishes, with a Pearson $\mathrm{R}$ of 0.770 . Therefore, we did not include both variables in the regression analysis. We selected the housing value variable for further analysis, because it provides an indicator of not only economic resources, but also tangible assets that may be damaged by floods. Since none of the other independent variables were found to have Pearson $R$ 
values of greater than 0.7 , these five were retained for inclusion in the regression analysis. The results of the Pearson analysis are summarized below in Table 6.

Table 6. Pearson correlation analysis.

\begin{tabular}{|c|c|c|c|c|c|c|c|}
\hline Independent Variable & $\begin{array}{l}\text { Total CRS } \\
\text { Points } 2013\end{array}$ & $\begin{array}{c}\text { \# CRS } \\
\text { Communities } \\
\text { per Parish }\end{array}$ & $\begin{array}{l}\text { Average } \\
\text { Elevation }\end{array}$ & $\begin{array}{c}\text { Median } \\
\text { House Value } \\
\text { per 1k }\end{array}$ & $\begin{array}{c}\text { College- } \\
\text { Educated } \\
\text { Rate }\end{array}$ & $\begin{array}{l}\text { \# of Total } \\
\text { Flood } \\
\text { Events } \\
\text { 2006-2010 }\end{array}$ & $\begin{array}{c}2010 \\
\text { Government } \\
\text { Revenue } \\
\text { per Person }\end{array}$ \\
\hline $\begin{array}{c}\text { Total CRS Points } \\
2013 \text { (score) }\end{array}$ & 1.000 & $0.65^{* * *}$ & -0.28 * & $0.66^{* * *}$ & $0.69 * * *$ & 0.11 & -0.28 \\
\hline \multicolumn{8}{|c|}{ Socioeconomics } \\
\hline Median Home Value & $0.66^{* * *}$ & $0.49^{* * *}$ & -0.22 & 1.00 & $0.77^{* * *}$ & -0.12 & 0.01 \\
\hline College Educated Rate & $0.69 * * *$ & $0.64 * * *$ & -0.14 & $0.77^{* * *}$ & 1.00 & 0.13 & -0.15 \\
\hline \multicolumn{8}{|c|}{ Government Capacity } \\
\hline CRS Communities & $0.65^{* * *}$ & 1.00 & -0.15 & $0.49 * * *$ & $0.64^{* * *}$ & 0.17 & -0.27 \\
\hline $\begin{array}{l}2010 \text { Government } \\
\text { Revenue per Person }\end{array}$ & -0.28 & -0.27 & -0.09 & 0.009 & -0.15 & -0.23 & 1.00 \\
\hline \multicolumn{8}{|c|}{ Exposure } \\
\hline Average Elevation & $-0.28 *$ & -0.15 & 1.00 & -0.22 & -0.14 & 0.010 & -0.09 \\
\hline $\begin{array}{l}\text { \# of total Flood Events } \\
\text { 2006-2010 }\end{array}$ & 0.11 & 0.17 & 0.010 & -0.12 & 0.13 & 1.00 & -0.23 \\
\hline
\end{tabular}

Notes: $N=35$; *** $p<0.01 ;{ }^{* *} p<0.025 ;{ }^{*} p<0.05$.

Next, we conducted a multiple regression analysis using the five selected independent variables. The results of the analysis are summarized in Table 7 below.

Table 7. Multiple regression analysis results.

\begin{tabular}{|c|c|c|c|c|c|}
\hline \multirow{2}{*}{ Model } & \multicolumn{2}{|c|}{$\begin{array}{l}\text { Unstandardized } \\
\text { Coefficients }\end{array}$} & \multirow{2}{*}{$\begin{array}{c}\begin{array}{c}\text { Standardized } \\
\text { Coefficients }\end{array} \\
\text { Beta }\end{array}$} & \multirow{2}{*}{$\mathbf{t}$} & \multirow{2}{*}{ Significance } \\
\hline & B & Standard Error & & & \\
\hline (Constant) & -594.70 & 386.90 & & -1.54 & 0.13 \\
\hline \multicolumn{6}{|c|}{ Socioeconomics } \\
\hline $\begin{array}{l}\text { Median Home Value } \\
\text { Government Capacity }\end{array}$ & 0.01 & 0.00 & 0.46 & 3.40 & 0.00 \\
\hline $\begin{array}{l}\text { CRS Communities } \\
2010 \text { Government Revenue per Person }\end{array}$ & $\begin{array}{l}218.80 \\
-5.38\end{array}$ & $\begin{array}{c}85.62 \\
3.51\end{array}$ & $\begin{array}{c}0.35 \\
-0.18\end{array}$ & $\begin{array}{c}2.56 \\
-1.53\end{array}$ & $\begin{array}{l}0.02 \\
0.14\end{array}$ \\
\hline \multicolumn{6}{|c|}{ Exposure } \\
\hline $\begin{array}{c}\text { Average Elevation } \\
\text { \# of total Flood Events 2006-2010 }\end{array}$ & $\begin{array}{l}-6.58 \\
13.53\end{array}$ & $\begin{array}{c}4.98 \\
24.39\end{array}$ & $\begin{array}{c}-0.15 \\
0.07\end{array}$ & $\begin{array}{l}-1.32 \\
0.55\end{array}$ & $\begin{array}{l}0.20 \\
0.58\end{array}$ \\
\hline
\end{tabular}

Notes: Dependent variable: total CRS points 2013. Model $p<0.001$, adjusted R squared $=0.571, N=35$.

The regression analysis yielded an adjusted $R$ squared of 0.571 , indicating that these five independent variables explained $57 \%$ of the variation in the parish CRS scores. Higher CRS scores are associated most closely with higher average housing values. The distribution of housing values within the study area is illustrated in Figure 2. This is not a surprising finding and indicates that parishes with more valuable built assets and likely more affluent residents have implemented more of the suggested actions to reduce flood risks. This finding is consistent with those of Sadiq and Noonan (2015) in their study of a sample of CRS communities throughout the nation and also those of Brody and colleagues (2009) in their examination of Florida counties [25,46]. The finding also is in keeping with prior research examining the more general attributes of communities that appear to enhance overall resilience to a range of large-scale disturbances. The findings of Lam et al., 2015, and Cutter et al., 2009 [37,47], for example, consistently point to the importance of socioeconomic resources in building resilience. 


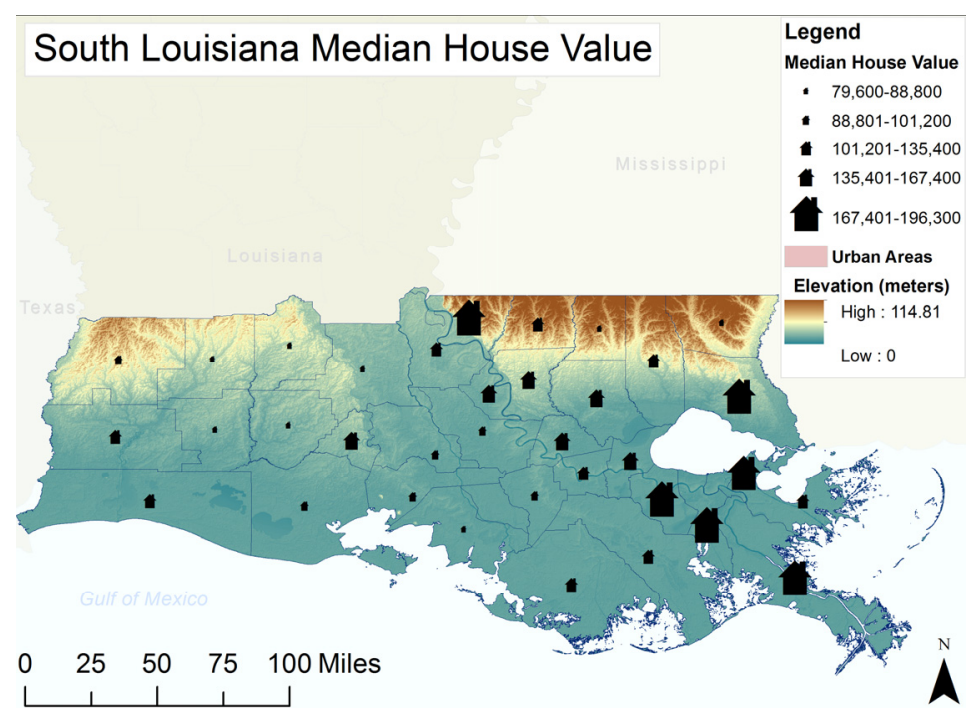

Figure 2. Map of housing values and elevations among parishes.

Regarding the capacity of the county governments, the presence of more municipalities participating in the CRS program within a parish is significantly associated with higher CRS scores at the parish level. This finding is not surprising and supports the conclusions of Landry and $\mathrm{Li}$ in their study of North Carolina counties' CRS participation from 1991 to 1996 [45]. The presence of more "nested municipalities" that are involved in the hazard mitigation planning encouraged by the CRS within a county may well increase the level of public awareness of the benefits of the collective actions and may provide a larger base of expertise and technical information to support the formulation and implementation of these measures. These factors may be particularly helpful to parish decision makers in Louisiana given the state's lack of a well-established culture of land use planning. The revenue base of the county government was not found to be significantly associated with the level of CRS program implementation.

The finding that average county elevation is not significantly associated with CRS planning activities is consistent with previous research of Florida counties conducted by Zahran in 2010 [24]. In Louisiana, it appears that mere location in a more low-lying and presumably more flood-prone area is not sufficient to prompt planners and policy makers to formulate and implement more CRS measures. One reason could be that planning and floodplain management activities in lower lying counties may be more difficult and expensive due to the larger amount of floodplain area [24]. We were somewhat surprised that the number of past flood events was not found to be related to CRS scores. This finding differs from the Zahran study in 2010 and suggests that among the south Louisiana parish decision makers, flood experience may be not sufficient to encourage the type of collective action specified by the CRS program. This finding may be further evidence of the short-term nature of risk perceptions found in earlier studies; that is, that past floods may fade from the memory of both residents and policy makers rather quickly [18]. The interest surrounding the development of collective plans and strategies for flood protection may not be as urgent a public policy issue as time progresses, if floods are not experienced regularly.

\section{Conclusions}

The objective of the analysis was to examine the context under which coastal parishes (counties) may be more likely to take steps to make themselves safer through floodplain management and other measures encouraged by the CRS program. The results of the regression analysis indicate that higher CRS scores are found in parishes with higher housing values and with a higher number of municipalities within the parish that also participate in the CRS program. Surprisingly, indicators of 
greater exposure to flood risks, including lower mean elevation and past flood events, were not found to be significantly associated with greater participation.

The CRS program is an important effort by the federal government to encourage local governments to become more proactive and adaptive in flood hazard mitigation planning. As the National Flood Insurance Program (NFIP) faces major deficits, this incentive-based approach to spur more collective floodplain management activities among county and local jurisdictions is compelling. Are there key contextual factors that may affect the extent to which local jurisdictions are willing or able to participate?

This analysis of southern Louisiana parishes indicates that acceptance of the incentives offered through the CRS program to move toward more collective hazard mitigation efforts may be influenced to a large extent by the socioeconomic attributes of the parish. These findings are consistent with prior related research in suggesting that more affluent communities with more valuable housing and property are more likely to achieve higher CRS scores. Furthermore, consistent with the Landry and Li study of counties in North Carolina, this analysis found that the presence of more local jurisdictions within the parish that also are participating in the CRS program is associated with higher county CRS scores [45]. The presence of these local CRS programs within the south Louisiana parishes may introduce more public support for the planning measures along with more technical expertise and resources for their implementation. By contrast, parishes with fewer socioeconomic resources and parish government capacity may face additional obstacles to formulating and implementing measures for collective flood hazard mitigation. This may be especially relevant in states like Louisiana, without a well-established history of local planning and where flood risks and NFIP premiums can only be expected to increase. As a result, the CRS program administrators may need to include additional outreach and technical assistance to lower income jurisdictions to encourage more collective action to reduce flood exposure risks to residents of flood-prone communities.

Acknowledgments: This material is based on work supported by the U.S. National Science Foundation under the Dynamics of Coupled Natural Human Systems (CNH) Program (Award Number 1212112). The statements, findings and conclusions are those of the authors and do not necessarily reflect the views of the funding agencies.

Author Contributions: Mary Paille created the tables and wrote the draft of the manuscript. Margaret Reams carried out statistical analysis, provided oversight throughout the study, and revised the manuscript. Jennifer Argote created tables and provided data for the study. Nina Lam provided oversight throughout the study and revised the manuscript. Ryan Kirby carried out statistical analysis and created the figures. All authors read and approved the final manuscript.

Conflicts of Interest: The authors declare no conflict of interest.

\section{References}

1. Ntelekos, A.; Oppenheimer, M.; Smith, J.; Miller, A. Urbanization, climate change and flood policy in the United States. Clim. Chang. 2010, 103, 597-616. [CrossRef]

2. U.S. Government Accountability Office. GAO-13-283, High Risk Series: An Update, 2013. Available online: http:/ / www.gao.gov/assets/660/652133.pdf (accessed on 15 December 2015).

3. Knowles, S.G.; Kunreuther, H.C. Troubled Waters: The NFIP in Historical Perspective. J. Policy Hist. 2014, 26, 327-353. [CrossRef]

4. Valacer, J. Thicker than Water: America's Addiction to Cheap Flood Insurance, 2015. Pace Law Rev. 2015, 35,1050 .

5. Villavaso, S.D. Planning enabling legislation in Louisiana: A retrospective analysis. Loyola Law Rev. 1999, 45,655 .

6. Federal Emergency Management Agency (FEMA). Changes to the Community Rating System to Improve Disaster Resiliency and Community Sustainability. Available online: http://www.fema.gov/ media-library-data/20130726-1907-25045-528/changes_to_crs_system_2013.pdf (accessed on 1 September 2015).

7. Federal Emergency Management Agency (FEMA). CRS State Profile: Louisiana. Available online: http://crsresources.org/files/200/state-profiles/la-state_profile.pdf (accessed on 2 December 2015). 
8. Federal Emergency Management Agency. Flood Smart Community Rating System. Available online: https://www.floodsmart.gov/floodsmart/pages/crs/community_rating_system.jsp (accessed on 1 August 2015).

9. Federal Emergency Management Agency (FEMA). National Flood Insurance Program Community Rating System Coordinator's Manual; FEMA: Washington, DC, USA, 2013.

10. Community Rating System Fact Sheet, October 2015. Available online: http://www.fema.gov/medialibrary-data/1444399187441-5293d81167caaf062c2925b75a69215f/NFIP_CRS_Fact_Sheet-Oct-8-2015.pdf (accessed on 15 December 2015).

11. Brody, S.D.; Zahran, S.; Maghelal, P.; Grover, H.; Highfield, W.E. The Rising Cost of Floods: Examining the Impact of Planning and Development Decisions on Property Damage in Florida. J. Am. Plan. Assoc. 2007, 73, 330-345. [CrossRef]

12. American Planning Association. Planning for Smart Growth; American Planning Association: Washington, DC, USA, 2002.

13. Conroy, M.M.; Iqbal, A.-A. Adoption of sustainability initiatives in Indiana, Kentucky, and Ohio. Local Environ. 2009, 14, 17. [CrossRef]

14. Reams, M.; Lam, N.; Baker, A. Measuring Capacity for Resilience among Coastal Counties of the US Northern Gulf of Mexico Region. Am. J. Clim. Chang. 2012, 1, 194-204. [CrossRef]

15. Randolph, J. Environmental Land Use Planning and Management; Island Press: Washington, DC, USA, 2004.

16. American Planning Association. Smart Growth Network; American Planning Association: Washington, DC, USA, 2011; pp. 1-29, 65-66.

17. Burby, R.; Deyle, R.; Godschalk, D.; Olshanky, R. Creating Hazard Resilient Communities through Land-Use Planning. Nat. Hazards Rev. 2000, 1, 99-106. [CrossRef]

18. Brody, S.D.; Highfield, W.E. Does Planning Work? J. Am. Plan. Assoc. 2005, 71, 159-175. [CrossRef]

19. Pottier, N.; Penning-Rowsell, E.; Tunstall, S.; Hubert, G. Land use and flood protection: Contrasting approaches and outcomes in France and in England and Wales. Appl. Geogr. 2005, 25, 1-27. [CrossRef]

20. Morelli, S.; Segoni, S.; Manzo, G.; Ermini, L.; Catani, F. Urban planning, flood risk, and public policy: The case of the Arno River, Firenze, Italy. Appl. Geogr. 2012, 34. [CrossRef]

21. Porter, J. Flood-risk management, mapping, and planning: The institutional politics of decision support in England. Environ. Plan. 2012, 44. [CrossRef]

22. Warner, J.; Buuren, A. Implementing Room for the River: Narratives of success and failure in Kampen, the Netherlands. Int. Rev. Adm. Sci. 2011, 77. [CrossRef]

23. Heintz, M.; Hegemeier-Klose, M.; Wagner, K. Towards a Risk Governance Culture in Flood Policy-Findings from the Implementation of the "Floods Directive" in Germany. Water 2012, 4. [CrossRef]

24. Zahran, S.; Brody, S.; Highfield, W.; Vedlitz, A. Non-linear incentives, plan design, and flood mitigation: The case of the Federal Emergency Management Agency's community rating system. J. Environ. Plan. Manag. 2010, 53, 219-239. [CrossRef]

25. Sadiq, A.; Noonan, D. Local capacity and resilience to flooding: Community responsiveness to the community ratings system program incentives. Nat. Hazards 2015, 78, 1413-1428. [CrossRef]

26. Fan, Q.; Davlasheridze, M. Flood Risk, Flood Mitigation, and Location Choice: Evaluating the National Flood Insurance Program's Community Rating System. Risk Anal. 2015. [CrossRef] [PubMed]

27. Gerbasi, J.; Division Manager/Recovery Planner, Terrebonne Parish Consolidated Government, Department of Planning and Zoning, Houma, LA, USA. Personal communication, 2015.

28. Adger, W.N.; Hughes, T.; Folke, C.; Carpenter, S.; Rockstrom, J. Social Ecological Resilience to Coastal Disasters. Science 2005, 309, 1036-1039. [CrossRef] [PubMed]

29. Community and Regional Resilience Institute. Definitions of Community Resilience, an Analysis; CARRI Report; Community and Regional Resilience Institute: Washington, DC, USA, 2013.

30. Cutter, S.; Burton, C.; Emrich, C. Disaster Resilience Indicators for Benchmarking Baseline Conditions. J. Homel. Secur. Emerg. Manag. 2010, 7, 24. [CrossRef]

31. Sherrieb, K.; Norris, F.H.; Galea, S. Measuring Capacities for Community Resilience. Soc. Indic. Res. 2010, 99, 227-247. [CrossRef]

32. Norris, F.H.; Stevens, S.P.; Pfefferbaum, B.; Wyche, K.F.; Pfefferbaum, R.L. Community resilience as a metaphor, theory, set of capacities, and strategy for disaster readiness. Am. J. Community Psychol. 2008, 41, 127-150. [CrossRef] [PubMed] 
33. Holling, C.S.; Gunderson, L.; Ludwig, D. Quest of a Theory of Adaptive Change: Understanding Transformations in Human and Natural Systems. In Panarchy; Gunderson, L.H., Holling, C.S., Eds.; Island Press: Washington, DC, USA, 2002; pp. 3-24.

34. Folke, C.; Hahn, T.; Olsson, P.; Norberg, J. Adaptive Governance of Social-Ecological Systems. Annu. Rev. Environ. Resour. 2005, 30, 441-473. [CrossRef]

35. Folke, C.; Carpenter, S.R.; Walker, B.; Scheffer, M.; Chapin, T.; Rockström, J. Resilience thinking: Integrating resilience, adaptability and transformability. Ecol. Soc. 2010, 15, 20.

36. National Research Council. Dam and Levee Safety and Community Resilience: A Vision for Future Practice; The National Academies Press: Washington, DC, USA, 2012.

37. Lam, N.; Reams, M.; Li, K.; Li, C.; Mata, L. Measuring Community Resilience to Coastal Hazards along the Northern Gulf of Mexico. Nat. Hazards Rev. 2015, 17. [CrossRef] [PubMed]

38. Drabek, T.E. Human System Response to Disaster. Health Policy 1986, 8, 368-369.

39. Luffman, I. Wake-up Call in East Tennessee? Correlating Flood Losses to National Flood Insurance Program Enrollment. Southeast. Geographer. 2010, 50, 305-322. [CrossRef]

40. Browne, M.; Hoyt, R. The Demand for Flood Insurance: Empirical Evidence. J. Risk Uncertain. 2000, 20, 291-306. [CrossRef]

41. Gares, P. Adoption of Insurance Coverage and Modes of Information Transfer: Case Study of Eastern North Carolina Floodplain Residents. Nat. Hazards Rev. 2002, 3, 126-133. [CrossRef]

42. Hodge, G. Planning Canadian Communities: An Introduction to the Principles, Practices, and Participants, 2nd ed.; Nelson Canada: Nelson, Toronto, ON, Canada, 1991.

43. Pearce, L. Disaster Management and Community Planning, and Public Participation: How to Achieve Sustainable Hazard Mitigation. Nat. Hazards 2003, 28, 211-228. [CrossRef]

44. Berke, P.R.; French, S.P. The influence of state planning mandates on local plan quality. J. Plan. Educ. Res. 1994, 13, 237-250. [CrossRef]

45. Landry, C.; Li, J. Participation in the Community Rating System of NFIP: Empirical Analysis of North Carolina Counties. Nat. Hazards Rev. 2012, 1061, 205-220. [CrossRef]

46. Brody, S.D.; Sahran, S.; Highfield, W.; Bernhardt, S.; Vedlitz, A. Policy Learning for Flood Mitigation: A Longitudinal Assessment of the Community Rating System in Florida. Risk Anal. 2009, 29. [CrossRef] [PubMed]

47. Cutter, S.L.; Smith, M.M. Fleeing from the hurricane's wrath: Evacuation and the two Americas. Environment 2009, 51, 26-36. [CrossRef]

(C) 2016 by the authors; licensee MDPI, Basel, Switzerland. This article is an open access article distributed under the terms and conditions of the Creative Commons by Attribution (CC-BY) license (http://creativecommons.org/licenses/by/4.0/). 